\title{
The Implementation of the Cameroon's French-English Official Bilingualism Policy: The Case of the Special Bilingual Education Programme in Secondary Level Education Institutions
}

\author{
Jean-Paul Kouega', Sandrine Dempowo ${ }^{2}$ \\ ${ }^{1}$ Department of English, University of Yaounde I, Yaounde, Cameroon \\ ${ }^{2}$ Ministry of Secondary Education, Yaounde, Cameroon \\ Email: jkouega@yahoo.co.uk
}

How to cite this paper: Kouega, J.-P. and Dempowo, S. (2022) The Implementation of the Cameroon's French-English Official Bilingualism Policy: The Case of the Special Bilingual Education Programme in Secondary Level Education Institutions. Open Access Library Journal, 9: e8221.

https://doi.org/10.4236/oalib.1108221

Received: November 30, 2021

Accepted: January 24, 2022

Published: January 27, 2022

Copyright $\odot 2022$ by author(s) and Open Access Library Inc.

This work is licensed under the Creative Commons Attribution International License (CC BY 4.0). http://creativecommons.org/licenses/by/4.0/

\section{Open Access}

\begin{abstract}
In 1961, Cameroon adopted the policy of French-English bilingualism and pledged to promote individual bilingualism in the country via education. Over the years, many programmes were experimented and they all failed to yield a high number of bilinguals. This article examines the latest programme put in place by the government in its effort to implement its French-English official bilingualism policy at the secondary education level. This programme, known as the "Special Bilingual Education Programme" (SBEP in short) started up with a few pilot schools in the year 2010 and was to be gradually extended to other schools in the country. The tools used to collect data for the survey include two questionnaires for pupils, one interview for teachers and another for school officials. The analysis of the data thus collected revealed that the SBEP programme being implemented in the country can definitely not produce even a small number of bilingual pupils by the time these pupils leave secondary school. The study proposes a new programme which, when implemented, will turn out a high number of competent French-English bilinguals in a relatively short period of time.
\end{abstract}

\section{Subject Areas \\ Education, Linguistics}

\section{Keywords}

Cameroon Bilingualism Policy, Bilingual Education, Individual Bilingualism, 
Language in Education, Language Policy Implementation

\section{Introduction}

Over the years, a laundry list of measures have been taken by Cameroon Governments to make its citizens bilingual and all these measures have produced very few competent bilinguals. The latest measure known as "Special Bilingual Education Programme" (SBEP in short) was designed to operate in secondary school institutions. It started up with a few pilot schools in the year 2010 and was to be gradually extended to other schools in the country. This study, which sets out to examine what has been achieved after one decade of implementation of this language acquisition programme, is guided by the following research questions: 1) How has the SBEP been implemented so far? 2) To what extent are the pupils involved satisfied with the programme? 3) What proportion of the pupils completes the programme? 4) How do the stakeholders, i.e., the pupils themselves and the school officials assess the bilingual competence acquired through this programme? The study is useful in that it will enable teachers, school inspectors, and the government to either generalise the teaching of the SBEP to all schools in the country or to discontinue its implementation and consider an alternative programme which can meet government's expectations. The work is divided into four sections labelled: background to the study (1), methodology (2), analysis (3), and discussions of the findings (4). These are considered in turn.

\section{Background to the Study}

This section considers in turn the language situation of Cameroon, the education system of the country, and the Special Bilingual Education Programme in Cameroon. In 1884, Cameroon became a German colony. In 1914, Germany lost the war and its possessions in Africa was shared by the victors. As far as Cameroon is concerned, 4/5 of the territory was given to France and 1/5 to Britain. In 1919, the League of Nations confirmed this annexation of the colony and the two territories were later referred to as West Cameroon and East Cameroon. In 1946, the United Nations was set up to replace the League of Nations and the two parts of Cameroon were renamed the UNO Trust Territories. In 1960, the part of Cameroon under French Trusteeship became independent, and adopted the name Republique du Cameroun (The Republic of Cameroon) with French as its official language. In 1961, part of the country under British Trusteeship became independent by joining The Republic of Cameroon, but with English as its official language. To seal this union, the leaders of the two states agreed to rename the country the Federal Republic of Cameroon, with French and English as its joint official languages. In addition, it was pledged in the 1961 Constitution that efforts would be made to make the country bilingual. Since then several lan- 
guages of different statuses co-exist in Cameroon: two official languages: French and English, three major minority languages: Pidgin English, Fulfulde and Beti, and over 250 lesser minority languages (see Kouega 2007) [1].

Concerning the education system of Cameroon, it can be pointed out that two sub-systems of education co-exist in the country: the Anglophone system, with English as its language of instruction, and the francophone system, with French as its language of instruction. In the French system, English is taught as a subject in all schools, and so is French in the Anglophone system. This is one of the measures taken up by government in its efforts to implement its French-English bilingualism policy. Several other measures which were taken since 1961 and which were discontinued for various reasons are outlined in Kouega (2018a) [2]. The latest measure, which was adopted in 2009, is referred to as the Special Bilingual Education Programme, the object of the present study. This programme, which was designed by the Ministry of Secondary Education to reinforce bilingual competence acquisition in the country, aims at teaching intensive French in English-medium schools on the one hand and intensive English in French-medium schools on the other hand. The present study focuses on the latter; it considers in turn pupils' enrolment procedure into the programme, the syllabus, teaching materials, teachers, and assessment.

\subsection{Enrolment Procedure}

In the secondary schools hosting this programme, all Sixième (Form One) pupils take a placement test of English and the 60 top pupils are brought together to form a special class called Sixième Bilingue. When these top pupils reached Troisième Bilingue (Form Four), they write the official examination called Brevet d'Etudes du Premier Cycle Bilingue, BEPC Bilingue in short. In Première Bilingue (Lower Sixth Form), they sit for the Probatoire Bilingue and in Terminale Bilingue (Upper Sixth Form), they sit for the Baccalaureat Bilingue (GCE Advanced Level). The programme started off with a few schools and is to be extended to all schools later.

\subsection{The Syllabus}

In the Sixième class (Form 1), ten subjects are taught in French and six in English, as Table 1 shows.

As Table 1 shows, ten subjects are taught in French for 23 hours a week and 5 subjects in English for nine hours a week.

The English language subject comprises two components, i.e., intensive English (3 hours) and literature awareness ( 2 hours). In the Intensive English class, various language-related activities are tackled including phonology, grammar, vocabulary, and reading comprehension. In the Literature awareness class, creative works are taught, with pupils being asked to present in class the summary of, say, a chapter of a novel, an activity aimed at enhancing their oral competence. The remaining subject include: Citizenship, Club activities, Sports, and 
Table 1. Subjects taught in the Sixième class.

\begin{tabular}{|c|c|c|c|c|}
\hline & $\begin{array}{l}\text { Subjects taught in } \\
\text { French }\end{array}$ & Weekly load & $\begin{array}{l}\text { Subjects taught in } \\
\text { English }\end{array}$ & Weekly load \\
\hline 1 & $\begin{array}{l}\text { Français } \\
\text { (French language) }\end{array}$ & 4 hours & English language & 5 hours \\
\hline 2 & $\begin{array}{l}\text { Mathématique } \\
\text { (Mathematics) }\end{array}$ & 3 hours & Citizenship & 1 hour \\
\hline 3 & $\begin{array}{l}\text { Histoire } \\
\text { (History) }\end{array}$ & 2 hours & Club Activities & 1 hour \\
\hline 4 & $\begin{array}{l}\text { Géographie } \\
\text { (Geography) }\end{array}$ & 2 hours & Manual labour & 1 hour \\
\hline 5 & $\begin{array}{l}\text { Informatique } \\
\text { (Computer sciences) }\end{array}$ & 2 hours & $\begin{array}{l}\text { Sport and physical } \\
\text { Education }\end{array}$ & 1 hour \\
\hline 6 & $\begin{array}{l}\text { Littérature } \\
\text { (Literature) }\end{array}$ & 4 hours & & \\
\hline 7 & $\begin{array}{l}\text { Langue et Culture } \\
\text { Camerounaises } \\
\text { (Cameroonian } \\
\text { languages and cultures) }\end{array}$ & 2 hours & & \\
\hline 8 & $\begin{array}{l}\text { Education Civique et } \\
\text { Morale } \\
\text { (Civics and morals) }\end{array}$ & 1 hour & & \\
\hline 9 & $\begin{array}{l}\text { Science de la Vie } \\
\text { et de la Terre } \\
\text { (Biology and zoology) }\end{array}$ & 2 hours & & \\
\hline \multirow[t]{2}{*}{10} & $\begin{array}{l}\text { Méthodologie } \\
\text { (Methodology) }\end{array}$ & 1 hour & & \\
\hline & Total number of hours & 23 hours & & 9 hours \\
\hline
\end{tabular}

Manual labour. For the Club activities subject, the pupils are encouraged to join the English club of their school. The last two subjects, i.e., Manual labour, and Sport and physical education, are usually not handled by English language teachers.

\subsection{The Teaching Materials}

The materials used in the SBEP are selected by the book selection commission set up by the Ministry of Secondary Education (MINESEC) to choose the books to be used in all schools in the country. In addition to the English textbooks chosen for all classes in the French-medium system of education, the SBEP pupils use other books for their Literature Awareness course. The 2016 academic year additional booklist for the SBEP classes is reproduced in Table 2. 
Table 2. The 2016 booklist for the SBEP programme classes.

\begin{tabular}{|c|c|c|c|c|}
\hline Classes & Books & Authors & Publishers & Years \\
\hline \multirow{3}{*}{$\begin{array}{l}\text { Sixième } \\
\text { (Form 1) }\end{array}$} & $\begin{array}{l}\text { 1) Tales from the grassland } \\
\text { and the forest }\end{array}$ & Agnes Ngoh Nzuh & Editions CLE & 2016 \\
\hline & 2) Short stories & Nsalai & Nnams & 2014 \\
\hline & 3) Undeserved sufferings & Njimeli & Peacock writing & 2014 \\
\hline \multirow{3}{*}{$\begin{array}{l}\text { Cinquième } \\
\text { (Form 2) }\end{array}$} & $\begin{array}{l}\text { 1) Finding one. The gifts and } \\
\text { the givers }\end{array}$ & Nyama & $\begin{array}{c}\text { The Catholic Printing } \\
\text { Press }\end{array}$ & 2016 \\
\hline & $\begin{array}{l}\text { 2) Chief Ayito and other } \\
\text { plays }\end{array}$ & Tanyi Tan & Eagle Publishing & 2016 \\
\hline & $\begin{array}{l}\text { 3) Journey to the centre of } \\
\text { earth }\end{array}$ & Jules V. & Macmillan & 2014 \\
\hline \multirow{3}{*}{$\begin{array}{l}\text { Quatrième } \\
\text { (Form 3) }\end{array}$} & 1) Eneta vs Elimo & Tanyi Tang & CLE & 2016 \\
\hline & $\begin{array}{l}\text { 2) Finding one. The gifts and } \\
\text { the giver }\end{array}$ & Nyama & $\begin{array}{c}\text { The Catholic Printing } \\
\text { Press }\end{array}$ & 2016 \\
\hline & 3) The return of the native & Thomas Hardy & Macmillan & 2014 \\
\hline \multirow{3}{*}{$\begin{array}{l}\text { Troisième } \\
\text { (Form 4) }\end{array}$} & 1) Best friends & Pechi Tamba & White House Publication & 2016 \\
\hline & 2) Unanswered cries & Osman C & Macmillan & 2014 \\
\hline & 3) A royal turmoil & Ngwa J. N. & ANUCAM & 2014 \\
\hline \multirow{3}{*}{$\begin{array}{l}\text { Seconde } \\
\text { (Form 5) }\end{array}$} & 1) Ten tales that tell & Nyah Sih Yonga & ANUCAM & 2016 \\
\hline & 2) Royal mail & Nforgwei Enoe & NMI Education & 2014 \\
\hline & 3) Inside the family & Ntikum Mbah Azonga & Fambata Publishers & 2016 \\
\hline \multirow{3}{*}{$\begin{array}{c}\text { Première } \\
\text { (Lower Sixth Form) }\end{array}$} & 1) Family saga & Bole Butake & CLE & 2016 \\
\hline & $\begin{array}{l}\text { 2) He would have made } \\
\text { himself }\end{array}$ & Ntumngia & Atlantic Press & 2016 \\
\hline & 3) Inside the family & Ntikum Mbah Azonga & Fambata Publishers & 2016 \\
\hline \multirow{2}{*}{$\begin{array}{c}\text { Terminale } \\
\text { (Upper Sixth Form) }\end{array}$} & 1) Son of the native soil & S. Ambanasom & ANUCAM & 2016 \\
\hline & 2) Animal farm & George Orwell & Heinemann & 2016 \\
\hline
\end{tabular}

\subsection{The Teaching Staff}

The teachers are graduates of three higher teacher training colleges in Cameroon, i.e., the universities of Bamenda, Maroua, and Yaounde I. Students who are holders of the Baccalauréat or the GCE A' Level are trained in these universities for three years while those holding the Licence (Bachelor degree) are trained for two. On completion of their training, they are posted to various secondary level schools in the country. Those taking up the SBEP programme receive no specialised or additional training in bilingual education.

\subsection{Assessment}

Like their mates in the ordinary English class, pupils in the SBEP programme are 
tested six times in a school year. These class tests are divided into two parts, one focusing on language and the other on literature. The language part includes exercises on grammar, vocabulary, reading comprehension, and essay writing. The literature part checks how well the pupils understood the creative works they read in class. These tests, which do not measure language proficiency, cannot tell whether the test taker is an elementary, intermediate, or advanced user of the language. What these tests measure is whether the test taker has scored, say, 50\% (i.e., average), $80 \%$ (i.e., excellent) or less than $50 \%$ (i.e., fail). They cannot tell whether the pupils who score $80 \%$ are capable of, say, asking for permission to go out of the classroom if the need arises. As a result, many pupils score very high marks without being capable of holding a short conversation in the target language. In short, the term "Special Bilingual Education Programme" in Cameroon shares very little with what researchers like Fishman (1970) [3], Mackey (1970) [4], Baker (2006) [5], Garcia (2008) [6], and Li Wei (2008) [7] refer to as "Bilingual education" in the literature.

\section{Literature Review}

Works on Cameroon's Special Bilingual Education Programme are rare, as it has been going on for barely ten years. One relevant study was conducted by Fondap Sienkep (2016) [8], who assessed the objectives of the programme. The purpose of this work was to check whether the objectives of the programme, which is to provide learners with greater opportunities to use their LO2 (official language 2) are attained in the schools considered. Three questions were set to guide the study. These are:

a) What do students and teachers see as milestones already accomplished seven years on?

b) How does the SBEP programme enhance the learning of the LO2, i.e., English for francophone pupils and French for Anglophone pupils?

c) What challenges and prospects do teachers and students hold for the SBEP programme?

The tools used for the study were a questionnaire, an interview and a production test. The informants were asked whether the SBEP programme did offer them enough opportunities to actually use their other language. These informants complained bitterly about the number of subjects they take, which they say is small, and the time allotted, which they find insufficient. These informants were also asked to indicate whether they thought they would be bilingual by the end of their training: $61.2 \%$ of the francophone informants said that they believed they would be bilingual while $38.8 \%$ believed they would not. Just about this same proportion was attained by the Anglophone informants learning French. Teachers handling the SBEP programme were asked to talk about the activities they do in class and they mentioned creative writing, short poems, language games and dramatization of some scenes in literature texts. Language teachers reported that their learners had no problem as far as the four language 
skills were concerned and both receptive and productive skills were developed. The teachers interviewed were unanimous in claiming that pupils in the SBEP classes were more proficient than those in the ordinary classes. A fairer evaluation of these pupils was obtained from their performance in official examinations. Of the 33 pupils who sat in for the special bilingual French subject in the GCE O' Level examinations in one school, no one failed: 21 (63.6\%) of the students scored an "A" grade in the SBEP subject, eight (24.2\%) scored a "B" grade and the remaining four (12.1\%) scored a " $\mathrm{C}$ " grade. As for the Probatoire exams, seven sat for the SBEP subject and two (28.5\%) had an " $\mathrm{A}$ " grade, two others a "B" grade, and the remainder a "C" grade, making a total of $100 \%$ pass. As for the production test, the results showed that the bilingual Anglophones learning French were apt, smart and fluent in their oral productions although they made a few grammatical mistakes. Bilingual francophones learning English were not fluent and their speech was punctuated by gestures and, on many occasions, they turned back to their mates to ask for the English equivalents of the words they knew in French but not in English. A comparison of the oral performance of the two groups of learners revealed that the Anglophones learning French were more bilingual than the francophones learning English. This finding was corroborated by the written production of these informants: francophone learners tended to think in French and then look for English words to convey their thought, which causes their speech to be full of gaps that surface in the form of pause or silence. The present work is a survey that attempts to quantify the views of the participants in the implementation of the intensive English programme in French-medium schools in the country.

\section{Methodology}

The setting of the study, the informants, the research instruments used, and the method of data analysis are taken up in turn.

\subsection{Setting of the Study}

The research was carried out in three grammar schools located in the Yaounde city, the names of which need not be disclosed here. These schools, which were selected at random among the schools harbouring the SBEP programme in the town, are referred to here as School 1, School 2 and School 3 when necessary. Yaounde schools were chosen because the designers of this programme as well a high number of school inspectors reside in this town. It is conjectured that the programme is likely to work better in this town than anywhere else in the country.

\subsection{Informants}

Three groups of people were contacted for the survey: pupils, teachers, and school vice-principals in charge of academic affairs. First, two sets of pupils enrolled in the SBEP programme were targeted. The first set included two pupils, 
one male and one female, from each of the five classes from Sixième (Form One) to Seconde (Form Five) from each of the three schools, i.e., a total of 30 informants. The second set included pupils of the Première class (Lower Sixth Form), on average 10 from each school, depending on availability; in all 30 pupils. The two sets of informants, which comprise a total of 60 subjects, are distributed as shown in Table 3.

The second group included teachers in charge of the SBEP classes. As the teachers handling this programme are limited in number, a small set of six teachers was constituted, two from each of the three schools mentioned above. Finally, three vice-principals, one from each of the three schools, were contacted. In short, the pool of informants for this study comprises 69 people: 60 pupils, six teachers, and three vice-principals.

These informants were very happy to meet someone who was interested in working on the issue of bilingualism in their schools, and their participation was voluntary. The teachers' and vice-principals' were told that the information they were to provide was to be published in a research work and that the names of their schools would not be mentioned. One vice-principal suggested that a copy of the published work be sent to the Government official in charge of education.

\subsection{Research Instruments and Method of Data Analysis}

The instruments used in the broad research from which this paper is extracted were made up of two questionnaires, two interviews, one class observation, and two production tests. Only the data from the questionnaires, interviews, and class observation are reported here. The two questionnaires (see Appendices 1 and 2) focused on the functioning of the programme, the capability of this programme to produce bilingual francophone pupils, the possibilities of the programme to produce large scale bilingualism in the country and possible suggestions for the improvement of the programme, as well as learners' motivation at different stages in their evolution in the programme.

The interview with teachers (Appendix 3) aimed to check whether they received a special training to teach the course, what skills they actually taught in class, the textbooks they used as well as their opinions about the capabilities of the programme to turn out a large number of bilinguals. The interview with the vice-principals (Appendix 4) focused on how the programme came into being in their schools, the number of teachers and pupils involved, as well as the problems they encountered in the implementation of the programme, and the

Table 3. Informants.

\begin{tabular}{|c|c|c|c|c|c|c|c|}
\hline Schools/Classes & Sixième & Cinquième & Quatrième & Troisième & Seconde & Première & TOTAL \\
\hline School 1 & 2 & 2 & 2 & 2 & 2 & 15 & 25 \\
\hline School 2 & 2 & 2 & 2 & 2 & 2 & 8 & 18 \\
\hline School 3 & 2 & 2 & 2 & 2 & 2 & 7 & 17 \\
\hline TOTAL & 6 & 6 & 6 & 6 & 6 & 30 & 60 \\
\hline
\end{tabular}


possibility of the programme to be extended to all schools. The classroom observation aimed at checking the number of students in each class, the classroom environment as well as the problems both teachers and pupils faced. Regarding the method of data analysis, the work is essentially a survey: the informants' responses are quantified and presented in the form of percentages.

\section{Analysis}

The data collected as outlined above are analysed, beginning with pupils' questionnaires (4.1). This is followed by the teachers' interview (4.2) and the vice-principals' interview (4.3).

\subsection{Pupils' Questionnaires}

Two questionnaires were designed for the pupils, one for Première pupils (30 subjects) and the other for the Sixième to Seconde pupils (30 subjects). These are considered simultaneously. The 30 Première informants were asked one key question, i.e., the reason for their enrolling in the SBEP programme or what motivated their enrolment (Q1).

Table 4 shows that $66.7 \%$ of 30 learners enrolled into this programme because they wanted to be perfectly bilingual, and a further $20 \%$ because the pupils on the programme were regarded as special and were therefore respected. Together, these two related answers give a total of $86.7 \%$. The informants who chose these two options fall into the "ideal self" category in Dornyei's (2009) [9] motivational framework. This researcher states that motivation for language learning falls into two broad categories, the "ideal self" and the "ought-to self" (Thompson, 2017) [10]. The "ideal self has a promotion focus", and learners are "able to

Table 4. Reasons for choosing the SBEP.

Q1. What motivated your enrolling into the Special Bilingual Education programme?

a) I wanted to become perfectly bilingual.

b) I love the fact that they are very few in the class.

c) The students in the programme are special and are respected.

d) My parents asked me to do it.

e) Others (specify).

\begin{tabular}{llcc}
\hline \multicolumn{1}{c}{ Motivational factor } & Number of informants & Percentage \\
\hline 1 & I wanted to be perfectly bilingual & 20 & $66.7 \%$ \\
2 & $\begin{array}{l}\text { The pupils in the programme are } \\
\text { special and respected }\end{array}$ & 6 & $20 \%$ \\
& $\begin{array}{l}\text { I love the fact that they are very few in } \\
\text { the class }\end{array}$ & - & - \\
4 & My parents asked me to do it & 4 & $13.3 \%$ \\
5 & Others & - & - \\
Total & 30 & $100 \%$ \\
\hline
\end{tabular}


utilise imagery to visualise who they would like to become in terms of target language use". The "ought-to self has a prevention focus" and is a manifestation of the external pressures that the learner feels in terms of target language use. Generally, the motivational strength of the ideal self is the strongest while that of the "ought-to self" is weaker. In this study, the learners fall in the "ideal self" category ( $86.7 \%$ of 30 pupils), as they were highly motivated when they started the programme. On the other hand, $13.3 \%$ were of the "ought-to" category, as they were asked by their parents to enrol in the programme.

Q2 asked these subjects to list and count the courses they were taught in French and in English during the school year and to indicate the number of hours of teaching per week. The answers are presented in Table 5 .

As Table 5 shows, ten courses were taught in French and six in English, which reflects the official syllabus outlined in Table 1 . The French courses were taught 23 hours a week and the English ones 9 hours a week. This means that, of a total of 32 hours of lectures a week, 23 were in French (71.9\%) leaving only nine to English (28.1\%). This imbalance does not augur well for the potentials of the course to make pupils bilingual.

Table 5. Number of courses taught in French and in English.

Q2. How many courses were taught in French during the school year? How many courses were taught in English? Write them down and indicate the number of hours per week.

\begin{tabular}{|c|c|c|c|c|}
\hline & Courses taught in French & Number of hours per week & Courses taught in English & $\begin{array}{c}\text { Number of hours } \\
\text { per week }\end{array}$ \\
\hline 1 & $\begin{array}{l}\text { Français } \\
\text { (French language) }\end{array}$ & 4 hours & Intensive English & 3 hours \\
\hline 2 & Mathématique (Mathematics) & 3 hours & Literature Awareness & 2 hours \\
\hline 3 & Histoire (History) & 2 hours & Citizenship & 1 hour \\
\hline 4 & Géographie (Geography) & 2 hours & Sport and physical Education & 1 hour \\
\hline 5 & $\begin{array}{l}\text { Informatique (Computer } \\
\text { sciences) }\end{array}$ & 2 hours & Club Activities & 1 hour \\
\hline 6 & Littérature (Literature) & 4 hours & Manual labour & 1 hour \\
\hline 7 & $\begin{array}{l}\text { Langues et Cultures } \\
\text { Camerounaises } \\
\text { (Cameroonian } \\
\text { languages and cultures) }\end{array}$ & 2 hours & & \\
\hline 8 & $\begin{array}{l}\text { Education Civique et Morale } \\
\text { (Civics and Morals) }\end{array}$ & 1 hour & & \\
\hline 9 & $\begin{array}{l}\text { Science de la Vie et } \\
\text { de la Terre } \\
\text { (Biology and geology) }\end{array}$ & 2 hours & & \\
\hline \multirow[t]{2}{*}{10} & Méthodologie (Methodology) & 1 hour & & \\
\hline & Total number of hours & 23 hours & & 9 hours \\
\hline
\end{tabular}


Asked to report on the actual activities that go on in the nine hours a week of English teaching (Q3), the pupils disclosed that they did four subjects, i.e., Intensive English, Literature Awareness, Citizenship, Club Activities, Sports and Physical Education, and Manual Labour. In the Intensive English class (three hours a week), they did Language use, which subsumes grammar, vocabulary, essay writing, reading comprehension, and oral communication. In the literature awareness class (two hours a week), on the other hand, they read drama, poetry, and prose, and considered literary notions. In the Citizenship class (one hour a week), they discussed notions and concepts like elections, and the arms of the government i.e., the executive, the legislative and judiciary. During Club Activities (one hour a week), they organised debates, exposés, and role plays. Regarding Sport and physical education (1 hour a week) and Manual labour (1 hour a week), the pupils reported that no activity was conducted. Informal discussions with the pupils, the teachers, and the vice-principals revealed why these courses were not taught. First, English teachers are not trained to teach sports and manual work; in most schools in the country, these two subjects are handled by sports teachers. Second, French teachers in non-bilingual programmes are never called upon to teach these two subjects and it is not clear why language teachers on the bilingual programme should be asked to teach them. For these two reasons, these two hours are usually lost, which reduces the learning period from nine hours a week to seven hours. Needless to say, even if the nine hours a week were fully occupied, they would not be sufficient to make someone bilingual in the context under scrutiny.

Asked whether they find any differences between them doing the SBEP and their classmates doing English as a subject (Q4), these informants made the revelations recorded in Table 6.

Table 6. Differences between the SBEP pupils and their non-SBEP classmates.

Q4. Do you find any differences - in the way you are treated or taught between you doing the SBEP and your classmates doing English as a subject?

a) Yes, more than $80 \%$ difference

b) Yes, about $50 \%$ difference

c) Yes, less than $50 \%$ difference

d) I am not really different/No difference at all Please justify your answer your answer?

\begin{tabular}{cccc}
\hline & $\begin{array}{c}\text { Differences between bilingual } \\
\text { pupils and other pupils }\end{array}$ & Number & Percentage \\
\hline 1 & $80 \%$ difference & 11 & $36.6 \%$ \\
2 & About 50\% & 9 & $30 \%$ \\
3 & Less than 50\% & 6 & $20 \%$ \\
4 & No difference at all & 4 & $13.3 \%$ \\
& TOTAL & 30 & $100 \%$
\end{tabular}


As these figures show, $36.6 \%$ of 30 informants reported an $80 \%$ difference while $30 \%$ claimed a $50 \%$ difference. Others $(20 \%)$ said the difference was less than $50 \%$, with some $13.3 \%$ not having noticed any difference at all. The justifications the SBEP group gave were that they had more subjects in English, their teachers paid more attention to them, and they did practical work in English such as debates, club activities, Bilingual Day activities, and presentations. Most importantly, they believed that they were more bilingual than their mates.

Q5 checked the languages they most frequently used for communication in a number of contexts. The answers are displayed in Table 7.

English seems to be dominant when the pupils were outside the classroom with their Anglophone friends ( $70 \%$ as opposed to French 30\%), in clubs $(80.8 \%)$ and in class with their English teachers (89.1\%). French was dominant when they were in class with their francophone mates (95.7\%), outside the class with francophone classmates (100\%), and at home with parents and siblings $(100 \%)$. Interestingly, when they were communicating with their teachers outside the classroom, 57.7\% used English while 42.5\% stuck to French. These figures suggest that the SBEP pupils tend communicate more frequently in French than in English.

Q6 asked the informants whether they were the only pupils who started the SBEP programme in Sixième (Form 1) and, if they were not, then where had their mates gone to. To avoid drawing one table for each of the three schools, the researchers added up the figures for the three Sixième classes of the three schools and divided the sum by three to find the averages, which are recorded in Table 8.

As Table 8 shows, all the 60 students of Sixième moved on to Cinquième (100\%). Then $97 \%$ of 60 went to Quatrième, and $88 \%$ of 60 went to Troisième. This decrease is due to a few cases of pupils who had to repeat a class or who were simply sent out of the programme, generally because of poor performance. After the class of Troisieme, the proportion of those who remained on the

Table 7. Languages most frequently used for communication.

Q5. Tick the languages you most frequently used for communication in the contexts listed below.

\begin{tabular}{lccc}
\hline & Situations & English & French \\
\hline 1. & In class with Francophone classmates & $4.3 \%$ & $95.7 \%$ \\
2. & Outside class with Francophone classmates & - & $100 \%$ \\
3. & Outside class with Anglophone friends & $70 \%$ & $30 \%$ \\
4. & Outside class in different clubs & $80.8 \%$ & $19.2 \%$ \\
5. & Outside class with your English teacher & $57.5 \%$ & $42.5 \%$ \\
6. & At home with parents, brothers and friends & - & $100 \%$ \\
7. & In class with your English teacher & $89.1 \%$ & $11.9 \%$ \\
\hline
\end{tabular}


Table 8. Number of pupils who started the SBEP programme in Sixième (Form 1).

Q6. Are you the only students who started the programme in your class?

a) Yes b) No. If no, where have the others gone to?

\begin{tabular}{ccccccc}
\hline Classes & $6 \grave{e}$ & $5 \grave{e ̀}$ & 4 è & 3 è & $2^{\text {nde }}$ & 1 ère \\
\hline $\begin{array}{c}\text { Number of pupils } \\
\text { in each class }\end{array}$ & 60 & 60 & 58 & 53 & 15 & 15 \\
$\begin{array}{c}\text { Proportion of pupils } \\
\text { who continued to the } \\
\text { next class }\end{array}$ & - & $100 \%$ & $97 \%$ & $88 \%$ & $25 \%$ & $25 \%$ \\
\hline
\end{tabular}

programme plunged to $25 \%$ of the initial 60 . This is due to the fact that in the Seconde class, francophone pupils are required to specialise: some go in for the sciences and others go in for arts. Given the overloaded curriculum of science pupils, it is difficult for them to proceed with the SBEP programme. This is precisely a conceptual error that the designers of this programme made; they assumed that most SBEP pupils will do arts when they get to Seconde. In short only $25 \%$ of the 60 pupils enrolled in Sixième can continue with the SBEP, which is a sheer wastage of resources. This finding answers the third research question (RQ3).

Q7 asked the 30 Première informants to cite some of the challenges and difficulties they face in their classrooms.

As Table 9 illustrates, abrupt exit from the SBEP programme is cited as the most serious problem these students face (36.6\% of 30$)$. In fact, science-inclined pupils leave the programme, thus taking with them their participation in class work, and their commitment and enthusiasm. Actually, the remaining pupils, who usually just about $25 \%$ of what their classes used to be, claim that the departure of their classmates makes them lose interest in the programme. The second major challenge is difficulty in understanding the lectures $(30 \%$ of 30 pupils), due to language teachers using "big words" and literature textbooks containing complex expressions. Many reported that they sought the assistance of their Anglophone friends to do the assignments they were given. In short, these pupils' vocabulary was limited and needed to be expanded. The third difficulty cited was negligence on the part of the administration (23.3\% of $30 \mathrm{pu}$ pils). These pupils believed they were special in their schools and therefore expected to be given special treatment by their school authorities. Unfortunately they said they were usually abandoned: their timetables were always the last to come out, their exams questions the last to arrive, long after their mates had started writing. It is not clear why they were treated this way but it may be due to their small number.

Q8 asked the pupils to propose possible solutions to the problems they thus identified. They suggested that, first, the administration and programme designers should find a way to include science-inclined pupils in the programme. Second, the teachers should use simple English and give them more time to process 
Table 9. Challenges and difficulties faced by the SBEP pupils in their classrooms.

\begin{tabular}{|c|c|c|c|}
\hline \multicolumn{4}{|c|}{ Q7. What are some of the challenges/difficulties you face in your classrooms? } \\
\hline & Pupils' problems & Number & Percentage \\
\hline 1 & $\begin{array}{l}\text { Abrupt exit from the programme after the } \\
\text { Troisième class }\end{array}$ & 11 & $36.6 \%$ \\
\hline 2 & Difficulty understanding the lectures & 9 & $30 \%$ \\
\hline 3 & $\begin{array}{l}\text { Negligence on the part of the administration } \\
\text { and teachers }\end{array}$ & 7 & $23.3 \%$ \\
\hline \multirow[t]{2}{*}{4} & Insufficient time and heavy work load & 3 & $10 \%$ \\
\hline & TOTAL & 30 & $100 \%$ \\
\hline
\end{tabular}

what they say. The teachers should also be more present in class and should work harder to help them to become bilingual. Third, prizes should be awarded to the best pupils to encourage them for their efforts and hard work, and these prizes should be handed over to them on special occasions like the Official Bilingualism Day. Fourth, the administration should construct appropriate and special classes for them to study in because the environment equally plays a great role in their learning. Lastly, during oral examinations, teachers should encourage them to work harder rather than insulting them when they answer questions poorly or in poor English.

Q9 checked the extent to which the pupils thought the training they received from the programme could be beneficial to them in their country or abroad. Their answers are brought together under the four headings in Table 10.

Table 10 shows that $43.3 \%$ of 30 pupils do not perceive how this programme can be of any help to them. In fact, they seem to have noticed that bilingual citizens in Cameroon do not get any specific advantage from their bilingual competence. Actually, in a study conducted by Kouega (2018a) [2], it was found that in Cameroon, officially bilingual citizens have no advantage over officially monolingual citizens, which is what discourages many people from expending efforts on bilingualism. Next, $30 \%$ of 30 pupils believed that their bilingual competence will help them to get good jobs, which is an instance of what Gardner (1985) [11] refers to as instrumental motivation. Some $13.3 \%$ reported that thanks to their bilingual competence, they will be able to communicate with their Anglophone friends, which can be regarded as an instance of integrative motivation. By so doing, they will be in good terms with English-speaking Cameroonians who, at the moment, are fighting for secession from francophone Cameroon for various reasons including lack of understanding (Kouega, 2018b) [12]. This is a laudable wish, but it cannot become true as the proportion of people nurturing the idea is very limited, barely $13.3 \%$ of 30 pupils. Finally, the remaining $13.3 \%$ disclosed that they simply wanted to attain the status of bilingual citizens.

Q10 asked the whole pool of 60 informants (30 Première pupils and 30 other pupils drawn from each of the preceding classes) to indicate whether they could 
Table 10. Projected benefits of the bilingualism programme.

Q9. What do you think this programme will help you to do in your country? How do you think it can be beneficial to you in your country or abroad?

\begin{tabular}{|c|c|c|c|}
\hline & Themes & Number & Percentage \\
\hline 1 & $\begin{array}{l}\text { The programme will not help me in } \\
\text { anyway }\end{array}$ & 13 & $43.3 \%$ \\
\hline 2 & $\begin{array}{l}\text { The programme will help me to } \\
\text { look for good jobs }\end{array}$ & 9 & $30 \%$ \\
\hline 3 & $\begin{array}{l}\text { The programme will help me } \\
\text { to communicate with } \\
\text { English-speaking friends }\end{array}$ & 4 & $13.3 \%$ \\
\hline 4 & $\begin{array}{l}\text { The programme will help me to be } \\
\text { a bilingual citizen }\end{array}$ & 4 & $13.3 \%$ \\
\hline & Total & 30 & $100 \%$ \\
\hline
\end{tabular}

Table 11. Proportion of pupils who would still choose the SBEP programme.

Q10. If you were given the opportunity to go back to Sixième, will you still choose the Special Bilingual Education Programme? A) Yes B) No. Explain why!

\begin{tabular}{ccc}
\hline Response & Number & Percentage \\
\hline Yes & 20 & $33.3 \%$ \\
No & 40 & $66.6 \%$ \\
Total & 60 & $100 \%$ \\
\hline
\end{tabular}

still choose the SBEP programme if they were to start in the Sixième class again.

The count of the answers reveals that $66.6 \%$ of 60 pupils said "No" (Table 11), meaning they would not choose the SBEP if they could go back to Sixième; they wondered why they wasted their time learning English when in the end they would have to abandon it in Seconde to do the sciences. On the other hand, 33.3\% disclosed that they would still enrol into this programme. This finding answers RQ2, as it is a clear indication that the pupils on this programme are satisfied with it only to a very limited extent.

Q11 asked the informants whether they would extend the programme to all schools in the country if they were the Minister of Secondary Education or adjust it before extending it. The 30 informants stated that they would adjust before extending it to the schools in the country. The reasons they gave to uphold their standpoints are grouped under the five headings in Table 12.

As Table 12 shows, the bulk of the pupils opted for an adjustment of the programme, mainly by including science pupils (33.3\%) and increasing the number of English teaching hours (30\%).

Q12 and 13 intended to check the pupils' motivation when they started the programme in Sixième and at the present time when they are in Première. 
Table 12. Reasons for adjusting the programme before extending it.

Q11. If you were the Minister of Secondary Education, will you adopt this programme as it is or adjust it so that it is used in all schools in the country? Justify your answer.

\begin{tabular}{llc}
\hline \multicolumn{1}{c}{ Reason } & Number & Percentage \\
\hline $1 \quad \begin{array}{l}\text { I will adjust the programme by including } \\
\text { science students }\end{array}$ & 10 & $33.3 \%$ \\
$\begin{array}{l}\text { I will adjust the programme by increasing } \\
\text { the number of English teaching hours }\end{array}$ & 9 & $30 \%$ \\
$3 \quad \begin{array}{l}\text { I will adjust the programme by removing } \\
\text { sports and physical education }\end{array}$ & 5 & $16.7 \%$ \\
$\begin{array}{l}\text { I will adjust the programme by building } \\
\text { appropriate classrooms }\end{array}$ & 4 & $13.3 \%$ \\
$\quad \begin{array}{l}\text { I will adjust the programme by increasing } \\
\text { the number of teachers }\end{array}$ & 2 & $6.7 \%$ \\
Total & 30 & $100 \%$ \\
\hline
\end{tabular}

Table 13 reveals that when these 30 pupils started the programme in Sixième, they all had a very high motivation (100\% of 30 ). Now in Première, $73 \%$ of 30 have a low motivation, with only $7 \%$ still having a high motivation. This finding answers RQ2, as it shows that the pupils are totally dissatisfied with the programme.

\subsection{Teachers' Interview}

An interview was designed to sample teachers' opinion on some seven aspects of the programme they were implementing. Two teachers from each of the three schools visited were contacted i.e., a total of six teachers. The first aspect these six teachers were made to discuss is their training; they were asked (Teacher Interview 1, in short TI1) whether they had received any special training that other English teachers in their schools had not received, and they gave the answers in Table 14.

All six teachers (100\%) reported that they had not received any extra training and added that they were simply assigned to teach the SBEP classes. In other words they were teaching English for bilingual competence in the same way as they teach English as a subject in a French-medium school system. Actually, as Kouega (2019) [13] observed, these teachers are not trained to handle bilingual education.

TI2 asked them whether they thought their pupils who had successfully gone through the SBEP programme would become bilingual. Their answers are reported in Table 15.

The main reason they gave to justify their negative answer was the limited time allotted to English teaching, barely nine hours a week, as was shown in Table 1. 
Table 13. Pupils' motivation.

Q12. When you started this programme in Sixième, your motivation was
a) high
b) average
c) low

Q13. Presently (in Première), your motivation is
a) high
b) average
c) low

\begin{tabular}{cccc}
\hline Motivation & High & Average & Low \\
\hline $\begin{array}{c}\text { At the beginning of the } \\
\text { programme (Sixième) }\end{array}$ & 30 & - & - \\
At the present time & $(100 \%)$ & $(0 \%)$ & $(0 \%)$ \\
$($ Première $)$ & 2 & 6 & 22 \\
\hline
\end{tabular}

Table 14. Special training received to teach in the SBEP classes.

TI 1. Have you undergone any special training to teach these SBEP classes?

\begin{tabular}{ccc}
\hline & Yes $(-)$ & No \\
Answers & - & $6(100 \%)$ \\
\hline
\end{tabular}

Table 15. Possibility of the pupils becoming bilingual.

TI 2. Do you think that your pupils who have successfully gone through the SBEP programme would become bilingual?

\begin{tabular}{ccc}
\hline & Yes (-) & No \\
Answers & - & $6(100 \%)$ \\
\hline
\end{tabular}

In TI3, they were asked a rhetorical question, namely, whether the number of pupils they train in their schools could help Cameroon to boast of large scale bilingualism in the nearest future. Again, they all gave a negative answer, as shown in Table 16.

This negative answer was expected. Actually, in Q10 above 60 pupils were asked whether they would still enrol in the SBEP programme if they were given the possibility to go back to Sixieme and only a meagre $33.3 \%$ said they would.

TI4 focused on the challenges these teachers faced with the implementation of the SBEP programme in their respective schools. The same problems were reported, including lack of adequate didactic materials, of a prescribed textbook and of teaching aids for the programme, low learners' motivation resulting from the exit of science-oriented pupils, and difficulty for the pupils to use English outside the classroom as they live in a francophone town, the classrooms themselves not being convenient for good learning.

Having got the teachers to point out the challenges they were facing, the researchers asked them (TI5) to discuss the strategies they used to overcome these difficulties. Regarding lack of understanding, some teachers resorted to code-switching or translation into French to enhance comprehension. Other teachers mentioned using general English books and materials drawn from the 
Table 16. Possibility for the number of pupils trained in the SBEP to impact the scale of bilingualism in the country.

TI 3. Do you think that the number of pupils you train in your schools can help Cameroon to boast of large scale bilingualism in the nearest future?

\begin{tabular}{ccc}
\hline & Yes $(-)$ & No \\
Answers & - & $6(100 \%)$ \\
\hline
\end{tabular}

internet to solve the problem of lack of a prescribed textbook for the SBEP programme. In addition, they reported that they encourage their pupils to speak English in and out of the classroom and most importantly, to listen to programmes in English on the radio and television as much as possible.

In TI6, the teachers were asked whether they would enrol their own children in the Special Bilingual Education Programme or recommend it to their relatives and friends. Their answers are presented in Table 17.

As the count shows, $50 \%$ of the six teachers said "yes" and the same proportion said "no". Those who said yes added that the pupils on the SBEP programme had an edge over the other pupils in their schools. Besides, they were far smarter and more intelligent than their peers in other classes and, thanks to the programme, they tended to perform better in other subjects. Those who said "no" expressed their concern over the poor conception and implementation of the programme. Its implementation rather confuses the learners and the teachers alike and this situation would ultimately push the pupils to abandon the programme for the non-SBEP classes. A comment one can make here is that those who said "yes" lost sight of the fact that the number of pupils that stayed on the programme kept on shrinking as the years went by.

\subsection{Vice-Principals' Interview}

Another interview was conducted with the vice-principals in charge in academic affairs of the three schools visited. The purpose of the interview was to collect additional information that could not be provided by the teachers and the pupils like the following: the year the programme started in their schools, the number of pupils in the schools, the difficulties faced by the school administration in the implementation of the programme and other such issues.

The first question (VPI1) each of the three vice-principals was asked focused on the circumstances which led to the creation of the SBEP programme in their schools and whether these schools still had the programme. The vice-principals revealed that a meeting with school inspectors was called up and they were informed that their schools had been chosen to harbour the SBEP. Then they were asked to provide a classroom for the programme. Actually, no prior investigation was done by the inspectors to check if the selected schools were ready to host the programme. From the first year, these vice-principals liberated some space where they could house the first batch and, as the years went by, they constructed other small classrooms for the programme. Lastly, they indicated that 
Table 17. Teachers' views on the SBEP programme.

TI6. Would you enrol your own children in the Special Bilingual Education Programme or recommend it to your relatives and friends? Why?

\begin{tabular}{ccc}
\hline Answers & Yes & No \\
& $3(50 \%)$ & $3(50 \%)$ \\
\hline
\end{tabular}

the programme was still running in these three schools. From this answer, one now understands why both the teachers and the pupils in the two preceding sections complained about poor teaching and learning environment: the programme was housed in makeshift classrooms hurriedly built with limited resources.

VPI2 asked the vice-principals to comment on the qualifications of the teachers involved in this programme in their schools. They were rather concerned by the fact that the number of English teachers in their schools was insufficient, with none of them being specialised in bilingual education. As a result, any English teachers they could lay hands on were used for the SBEP programme. As they were few teachers, so their workload was heavy. Needless to say, in such a context, teaching can hardly be effective.

In VPI3, the vice-principals were asked to comment on the proportion of the SBEP pupils and the non-SBEP pupils in the schools. One of them provided quantitative data. He reported that in Sixième, a total of 360 pupils are enrolled every year and they are distributed into six classes. After two weeks of teaching, they are subjected to an English language test and the top 60 pupils are brought together to form the SBEP class and the remaining 300 pupils form the non-SBEP classes. These 60 pupils are expected to go through the programme till its completion. However, many leave halfway for various reasons including poor performance and specialisation in the class of Seconde. The figures from this school are presented in Table 18.

As these figures show, of the 60 pupils who enrolled on the programme in Sixieme, only 15 (25\% of 60 pupils) reached the Seconde class. This is a good example of wastage of scarce resources.

VPI4 focused on the problems faced by teachers and pupils and how they were resolved. The vice-principals reported that some classrooms were built, specific timetables were drafted, a few more teachers were posted, and a series of seminars were organised. What has not been broached is the sharp drop that happens in Seconde when as many as $75 \%$ of 60 pupils leave the programme for the sciences. It is to be recalled that these pupils said earlier that when they leave the programme, they lose the little English they had acquired.

In short, this section has outlined the functioning of the SBEP programme in three schools from the point of view of the pupils, teachers and vice-principals and has shown that there are a number of shortcomings which make its extension difficult. 
Table 18. Proportion of SBEP pupils and non-SBEP pupils in one school.

\begin{tabular}{cccc}
\hline 3. What is the proportion of SBEP and non-SBEP pupils in your school? \\
\hline Classes & $\begin{array}{c}\text { Number of SBEP } \\
\text { pupils }\end{array}$ & $\begin{array}{c}\text { Number of } \\
\text { non-SBEP pupils }\end{array}$ & $\begin{array}{c}\text { Total number of } \\
\text { pupils in the } \\
\text { school }\end{array}$ \\
\hline Sixième & 50 & 300 & 360 \\
Cinquième & 54 & 302 & 360 \\
Quatrième & 54 & 306 & 360 \\
Troisième & 15 & 306 & 360 \\
Seconde & 15 & 345 & 360 \\
Première & & 345 & 360 \\
\hline
\end{tabular}

\section{Discussion of the Findings}

This section discusses the findings of the study, focusing on the issues which hamper the implementation of the programme (5.1). Then it proposes a new bilingual programme that can overcome these difficulties and can, at the same time, turn out a large number of bilinguals in the country (5.2).

\subsection{The Challenges of the SBEP}

Throughout this study, the informants, i.e., school pupils, teachers, and vice-principals in charge of academic affairs, have cited various stumbling blocks that affect the implementation of the SBEP programme. To begin with, the learners who are highly motivated at the beginning of the programme, tend to lose interest as the years go by. They complain about the difficulties they face in understanding lectures and the abrupt exit of their classmates after Troisième. They feel that they are neglected by the administration of their schools including their teachers, and that their workload is heavier than that of their mates in the non-SBEP programme. Halfway into the programme, some pupils ( $43.3 \%$ of 30 informants) are demotivated because they are expending too much effort on a programme that will not help them in any way so much so that many of them (66.6\% of 60 informants) would not enrol into the programme if they were taken back to Sixième. All the pupils believed that the programme needs to be adjusted so that it should include science students and a greater number of teachers and of teaching hours. They recommended that classrooms more conducive to learning should be built for them and subjects like sports and physical education be removed from the list of the bilingual subjects they are taught. All of these problems affected the pupils' motivation: while they started the programme with a very high motivation ( $100 \%$ of 30 pupils), toward the end, many of them declared that they had lost interest (73\% of 30 pupils).

The teachers, on their part, disclosed that the programme cannot make the pupils bilingual, given the fact that they lack adequate teaching materials and teaching aids in a context of low learner motivation. On the basis of the above, 
only $50 \%$ of six teachers can recommend this programme to their relatives and friends. As for the vice-principals, they reported that they did not have enough English teachers for their schools and those teaching on the programme had not received any special training. The most challenging problem for them is the fact that the proportion of pupils on the programme is very small, and this number drops considerably (up to 75\%) in Seconde. As a result, the pupils who leave lose the little English they had learnt. As can be seen, this litany of difficulties cannot be overcome; there is therefore a need to design a new programme rather than trying to adjust or fine-tune the present one.

\subsection{A Proposed Bilingual Programme}

To begin with, there is a need to define bilingualism in the context of Cameroon, design a new school syllabus, and explain the benefits of this new syllabus to the stakeholders. First, State officials must define bilingualism in a way that it is perceived that Government is enthusiastic about its official policy of French-English bilingualism. For such a definition to be convincing, it must include an economic aspect; actually the acquisition of bilingual competence is investment and the returns should be palpable. As Government operates with civil servants, it should define a bilingual civil servant as someone who can do the job for which he is paid in both French and English. To do one's job in these two languages, one must have successfully completed at least primary education in the two official languages. The exit certificates at the primary level of education in Cameroon are known as the Certificat d Etudes Primaires (CEP) and the First School Leaving Certificate (FSLC). These two certificates must therefore be required for recruitment into the civil service as well as promotions and appointments of civil servants.

Second, a new school syllabus that includes a bilingual competence component has to be set up. The bilingual competence course should start at the secondary school level, i.e., Sixième for French-medium schools and Form One for English-medium school. The course content must be organised in such way that by the time the francophone learner completes the Sixième class, he has also completed the primary school Grade One class. Similarly as the Anglophone learner completes Form One, he must have been taught the subject content of the Section d Initiation au Language (SIL), which is the first year of primary education in French-medium schools. If this pairing of classes is done systematically (see details in Kouega 2005 [14], 2019 [13]), then, by the time a learner obtains the secondary school exit certificate in one school medium, say French, he would also obtain the first school exit certificate in the other school medium, say English.

Third, the benefits of this new programme are enormous. It solves all the problems that are hampering the implementation of the current programme and it is cost-effective in the sense that all secondary school leavers would be fully bilingual, which is not the case today. The teachers are available and a high num- 
ber can be trained in just one academic year. One priceless benefit is peace and living together: what is termed the Anglophone problem in Cameroon (Konings and Nyamnjoh 1997 [15]; Kouega 2018b [12]) is a movement that was triggered by the attitude of French-speaking civil servants who knew no English and who communicated with their subordinates only in French in an English-speaking environment, causing some of these subordinates to feel that they were being lectured in French in their own land.

\section{Conclusion}

This study has examined the implementation of the Cameroon's French-English official bilingualism policy in secondary schools via the Special Bilingual Education Programme. This programme was designed to produce a high number of bilingual pupils by teaching them some of their courses in their other official language, i.e., French in English-medium schools and English in French-medium schools. This programme which has been going on for over a decade, falls short of expectations as it fails to train even a small number of competent bilinguals, as all science-inclined pupils exit from it after the Troisieme class. The stakeholders involved, i.e., the pupils proper, the teachers and the vice-principals all assess the programme negatively, with a high proportion of pupils reporting that their high motivation at the beginning of the course dropped sharply at they were moving on. The designers of the programme, who are secondary school teachers occupying duty posts at the Ministry of Education, do not seem to have consulted specialists in the domain who could have pointed out the difficulties affecting the implementation of the programme. For example, it was obvious from the start that after Form Four, science-inclined pupils could not stay in the programme. Because the programme cannot do what it was designed for, there is a need to work out an alternative that is easier to implement and that can turn out a greater number of bilinguals. This new programme first defines bilingualism in terms of the benefits it can procure and then shows how through education, the bulk of secondary school goers can actually acquire bilingual competence at limited cost for the stakeholders.

\section{Conflicts of Interest}

The authors declare no conflicts of interest.

\section{References}

[1] Kouega, J.P. (2007) The Language Situation in Cameroon. Current Issues in Language Planning, 8, 3-94. https://doi.org/10.2167/cilp110.0

[2] Kouega, J.P. (2018) The benefits of French-English bilingual competence in Cameroon. Open Access Library Journal, 5, e4409.

[3] Fishman, J.A. (1970) The Politics of Bilingual Education. In: Alatis, J.E., Ed., Bilingualism and Language Contact, Georgetown University Press, Washington DC, 47-58.

[4] Mackey, W.F. (1970) A Typology of Bilingual Education. In: Andersson, T. and 
Boyer, M., Eds., Bilingual Schooling in the United States, Vol. 2, Southwest Educational Development Laboratory, Austin, Texas, USA, 65-83.

[5] Baker, C. (2006) Foundation of Bilingual Education and Bilingualism. 4th Edition, Multilingual Matters, Clevedon, England.

[6] Garcia, O. (2008) Bilingual Education in the 21st Century: A Global Perspective. Wiley-Blackwell, New York.

[7] Li, W. (2008) Research Perspective in Bilingualism and Multilingualism. In: Li, W. and Moyer, M.G., Eds., The Blackwell Guide to Research Methods in Bilingualism and Multiculturalism, John Willey \& Sons, London, 3-17.

[8] Sienkep, F. (2016) An Assessment of the Objectives of the Special Bilingual Education Programme Seven Years on: Case Study of Terminale and Upper Sixth Students of Three Secondary Schools in Yaounde. Unpublished Postgraduate Dissertation, ENS, University of Yaoundé I, Yaoundé.

[9] Dornyei, Z. (2009) The L2 Motivational Self System. In: Dornyei, Z. and Usioda, E., Eds., Motivation, Language Identity and L2 Self, Multilingual Matters, Bristol, 9-42. https://doi.org/10.21832/9781847691293-003

[10] Thompson, A.S. (2017) Language Learning Motivation in the United States: An Examination of Language Choice and Multilingualism. The Modern Language Journal, 101, 483-500. https://doi.org/10.1111/modl.12409

[11] Gardner, R.C. (1985) Social Psychology and Second Language Learning. Edward Arnold, London.

[12] Kouega, J.P. (2018) The Anglophone Problem in Cameroon: Focus on Education. Open Access Library Journal, 5, e4408. https://doi.org/10.4236/oalib.1104408

[13] Kouega, J.P. (2019) The English of Francophone Speakers in Cameroon. GRIN Verlag, Munich. https://www.grin.com/document/505457

[14] Kouega, J.P. (2005) Promoting French-English Individual Bilingualism through Education in Cameroon. Journal of Third World Studies, 22, 185-196.

[15] Konings, P. and Nyamnjoh, F.B. (1997) The Anglophone Problem in Cameroon. The Journal of Modern African Studies, 35, 207-229.

https://openaccess.leidenuniv.nl/bitstream/handle/1887/4616/ASC-1246231-023.pdf ;sequence $=1$

https://doi.org/10.1017/S0022278X97002401 


\section{Appendix 1}

\section{Pupils' Questionnaire (Première Class)}

I am a graduating student of the Higher Teachers' Training College (ENS) Yaounde. As part of my curriculum, I am currently carrying out a research on the Special Bilingual Education Programme in some secondary schools in Yaounde. As a student enrolled in this programme, you have been chosen to contribute to this study by filling in this questionnaire. Your participation in this sense will depend on your honesty and the sincerity of your answers. We assure you that your response will be kept confidential and only be used for academic purposes.

Please, write your answers in the spaces provided.

Biodata

Are you male or female?

What is your region of origin?

1) What motivated your enrolling into the Special Bilingual Education programme?

a) I wanted to become perfectly bilingual.

b) My parents asked me to do it.

c) I love the fact that they are very few in the class.

d) The students in the programme are special and are respected.

e) Others (specify).

2) How many courses were taught in French during the school year? How many courses were taught in English? Write them down and indicate the number of hours per week.

3) What activities actually went on during the periods of English teaching?

4) Do you find any differences between you doing the SBEP and your classmates doing English as a subject?

a) Yes, more than $80 \%$ difference

b) Yes, about $50 \%$ difference

c) Yes, less than $50 \%$ difference

d) I am not really different/No difference at all

Please justify your answer your answer?

5) Tick the languages you most frequently used for communication in the contexts listed below.

\begin{tabular}{llll}
\hline \multicolumn{1}{c}{ Contexts } & English & French \\
\hline 1. & In class with Francophone classmates & \\
2. & Outside class with Francophone classmates & \\
3. & Outside class with Anglophone friends & \\
4. & Outside class in different clubs & \\
5. & Outside class with your English teacher & \\
6. & At home with parents, brothers and friends & \\
7. & In class with your English teacher & \\
\hline
\end{tabular}


6) Are you the only students who started the programme in your class? a) Yes b) No. If no, where have the others gone to?

7) What are some of the challenges/difficulties you face in your classrooms?

8) Can you propose some possible solutions to the problems you have identified?

9) What do you think this programme will help you to do in your country? How do you think it can be beneficial to you?

10) If you were given the opportunity to go back to Sixième, will you still choose the Special Bilingual Education Programme? A) Yes B) No. Explain why!

Q11) If you were the Minister of Secondary Education, will you adopt this programme as it is or adjust it so that it is used in all schools in the country? Justify your answer.

Q12) When you started this programme in Sixième, your motivation was

a) high b) average c) low

Q13) Presently (in Première), your motivation is

a) high b) average c) low

\section{Appendix 2}

\section{Pupils' Questionnaire (Sixième to Seconde Classes)}

I am a graduating student of the Higher Teachers' Training College (ENS) Yaounde. As part of my curriculum, I am currently carrying out a research on the Special Bilingual Education Programme in some secondary schools in Yaounde. As a student enrolled in this programme, you have been chosen to contribute to this study by filling in this questionnaire. Your participation in this sense will depend on your honesty and the sincerity of your answers. We assure you that your response will be kept confidential and only be used for academic purposes.

Please, write your answers in the spaces provided.

Biodata

Class

Are you male or female?

What is your region of origin?

1) (6) Are you the only students who started the SBEP programme in your class? a) Yes b) No. If no, where have the others gone to?

2) (10) If you were given the opportunity to go back to Sixième, will you still 
choose the Special Bilingual Education Programme? A) Yes B) No. Explain why!

\section{Appendix 3}

\section{Guide for Interview with Teachers}

1) Have you undergone any special training to teach these SBEP classes?

2) Do you think that the pupils in this programme will become perfectly bilingual by the time they are in lere or Tle classes? Answer YES or NO and explain your answer.

3) Do you think that the number of pupils you train in your school can help Cameroon to boast of large scale bilingualism in the nearest future? Why?

4) According to you, what are the challenges teachers face with the implementation of this programme?

5) How do you cope with these challenges?

6) Would you enroll your own children in the Special Bilingual Education Programme or recommend it to your relatives and friends? Why?

\section{Appendix 4}

\section{Guide for Interview with Vice-Principals}

1) How did the bilingual classes come into existence in your institution?

2) What are the qualifications of the teachers handling the Special Bilingual Education Programme in your school?

3) How many students are admitted into the Sixieme classes of your school each year? How many are selected for the Sixième Bilingue Spéciale?

4) What are some of the difficulties faced by the teachers in this programme and the pupils? Have you succeeded in solving these problems? 